Keywords: Place identity; creative districts; urban regeneration; art districts; urban renewal in China.

\section{PLACE IDENTITY AND CREATIVE DISTRICT REGENERATION: THE CASE OF 798 IN BEIJING AND M50 IN SHANGHAI ART ZONES}

\section{Marichela SEPE*}

\section{INTRODUCTION}

The history of a place, and in particular its historic urban fabric and heritage, constitutes - together with the development of suitable policies an important element in determining the future of that part of the city and its renewal (Pendlebury, 2014).

Places are termed "places" and not just "spaces" when - as many scholars of the city demonstrate - they are endowed with identity (Hague and Jenkins, 2005). The identity of a place expresses a harmonious balance between variant and invariant components, people and urban events, which are intrinsically linked by a reciprocal relationship that makes a specific place unique and recognizable (Lynch, 1960). Globalization and technological development have contributed to accelerating the rates of change and transforming spaces in the contemporary city. The result is that cities, places, itineraries, customs and behavioural patterns have all come to resemble one another, contributing to an increasing urban identity crisis (Bentley, 1999; Christensen, 1999; Harvey, 2006, Massey, Jess, 1995; Jiaming, Scott, 2013). "Many trends towards homogenisation of and loss of meaning in, places relate to processes of globalisation and the creation of global space, through improved communications (whether physical or electronic). Globalisation is a multi-faceted process in which the world is becoming increasingly interconnected, with centralised decision-making exploiting economies of scale and standardisation. The changing, and problematizing, of relationships between local and global has significant implications for what constitutes the meaning of place. Castells (1989, p.6) described the effects of information technology in the creation of a space of flow which dominates the historically constructed space of places. (...) With globalisation has come "mass" culture, emerging from the processes of mass production and consumption, which homogenises and standardises culture and places, transcending, crowding out, even destroying, local cultures. According to Crang $(1998,115)$, much of the worry over 
"placeness" can be interpreted as fear that local, supposedly "authentic" forms of culture - made from, and making, local distinctiveness - are being displaced by mass-produced commercial forms imposed on the locality" (Carmona et al., 2010, 124-5).

At the same time, recognising the value of place identity (Lynch, 1960) as a fundamental component of heritage and in implementing urban change serves as a reference point both in terms of society's wishes and in safeguarding and constructing the sustainable urban image. Built heritage narratives facilitate the creation and enhancement of national identities by "denoting particular places as centres of collective cultural consciousness" (Gospodini, 2004). Cities have to find out how to reduce the risks inherent in the tendency of contemporary urban societies to fall back on their heritage and historical roots as they face up to an identity crisis. (Erdoğanaras et al, 2013). In this respect, innovation and creativity in urban space represents an opportunity to construct an identity of places and give a no globalized scope to the urban form of contemporary cities (Chen, Thwaites, 2013) Creativity (Florida, 2005) and industry of culture cover a huge set of activities fundamental to launch a country's economy, nonetheless it is important to consider that the most successful urban regeneration projects are those where there is a strong involvement of local pre-existing identity and where history recovery of the sense of place and belonging to the local community is expected (Sepe, 2010a-b).

Starting from these premises, the aim of the paper is to illustrate the concepts of place identity and creative regeneration assuming that place identity is a fundamental factor in creative operations of transformation. As regards, the role of artist in these operations of urban transformation will be illustrated as an important element to understand the cultural change of a place. The topics will be explained with an international point of view and then centred on Chinese cities which in the last years are changing their image through many operations of cultural and creative regeneration. As a way of examples, the process of regeneration, concerning two creative sites in China, is illustrated: 798 district in Beijing and M50 in Shanghai. These districts have in common the transformation of old industry into a creative park and two phases of development. Due to increasing economic growth, which is the case in many Chinese cities, the risk is the globalization of the process of regeneration and the loss of place identity. The paper is organized as follows: section 2 is devoted to theories on place identity; section 3 illustrates the factors which influence creative regeneration and the role of artists in these operations; section 4 illustrates the methodology; section 5 describes the two case studies with particular attention both to the history of the place and the transformation in Art Districts. As regards, the identification of strengths and weakness in the description of these operations will complete the paper. Finally section 6 draws the conclusions.

\section{THEORIES ON PLACE IDENTITY}

The notion of identity is a fundamental phenomenon, which is difficult to define although it is possible to recognize many of its characteristics (Sepe, 2013). The starting definition is that asserted by Relph $(1976,45)$, who identifies the difference between "identity of" and "identity with", which is useful to gain a clearer idea of this concept. "The identity of something refers to a persistent sameness and unity which allows that thing to be differentiated from others. Such inherent identity is inseparable from 
identity with other things; Erik Erikson $(1959,1029)$, in a discussion of ego identity, writes: "The term identity ... connotes both a persistent sameness with oneself ... and a persistent sharing of some kind of characteristic with others". Thus, identity is founded both in the individual person or object and in the culture to which they belong. It is not static and unchangeable, but varies as circumstances and attitudes change; and it is not uniform and undifferentiated, but has several components and forms (Relph 1976, 45).

Indeed, Watson and Bentley $(2007,6)$ observe that place identity matters a wide range of people. This is easy to understand if we focus on the relationships between identities related to humans and a different set of meanings which affect the cultural landscape: "for us, place identity is the set of meanings associated with any particular cultural landscape which any particular person or group of people draws on in the construction of their own personal or social identities" (Bentley 2007, 6).

Hague and Jenkins highlight the existence of both individual and collective (Lawler, 2013) definitions of place identity related to different ideas of the area within which one lives. "In an increasingly complex society, overlapping definitions of place identity exist -again both individually and in a collective manner. The manifestation of these forms of social identity is what has been termed mind-maps whereby we register physical space mentally. Thus if asked to describe, for instance, the area which they live within, members of the same household will define this area differently based on their perception and activities within it, and will use different physical attributes to describe this. More than this, an individual household member is quite likely to use different mind-map references when describing the same area to different people, and would probably describe the same place in different ways with the passage of time" Hague and Jenkins $(2005,20)$.

This is demonstrated by the fact that the experience of place assumes relational meanings rather than being merely subjective. "This means that our capacity to identify a place as a place is shaped by what others tell us about the place, and filtered by our socialization, as shaped by class, age, gender, ethnicity, nationality, professional education, etc. As Rose (1995, 88) commented, "although sense of a place may be very personal, they are not entirely the result of one individual's feelings and meanings". It is this process of receiving, selectively reconstructing, and then re-communicating a narrative that constitutes identity and transforms a space into a place" (Hague and Jenkins $(2005,5)$.

Furthermore, Proshansky (1983) links the various kinds of relationships between people and their experiences: "Thus, place identity is the result of a constant and often subconscious negotiation between individuals and the potpourri of experiences, objects, and even idealized places they encounter during their lives".

Place identity can also be related to the concept of authenticity, which Southworth and Ruggeri (2010) define as "the quality of a place being unique, distinctive, and rooted in the local. Place identity assumes significance also in relation to its public meaning which in turn influences and stimulates citizen participation". In this connection, Southworth and Ruggeri $(2010,495)$ observe that "Place significance may also result from historic or political events. But places with strong public identity need not have strong visual identity. (...) While strong visual form is not essential for identity, it can provide a framework for attaching meanings. Place identity 
has greatest power when visual form, individual and social meaning come together. Indeed, according to Lynch (1960), (S)ense of place in itself enhances every human activity that occurs there, and encourages the deposit of a memory trace".

Accordingly, the relationship between heritage, place identity and planning (Graham and Howard, 2008; Kong, 2007) is important in order to understand - as in the following Chinese case studies - the history of the place and preserving it through suitable actions of planning. The preservation of the memory of the place represented in a different way - both tangible and intangible - is the main factor to avoid the risk of globalization or strong territorial marketing (McCarthy, 2006; McDowell, 2008; Pozo, Gonzales, 2012).

The various definitions which have been reported suggest, as was observed by Southworth and Ruggeri $(2010,510)$, that this concept "should be thought of as a gradient that includes several dimensions and should be as complex as the processes at play in every neighbourhood. It should account for aesthetic appeal and imageability, but be expanded to include social considerations, the discourses and meanings that are shared by community members". This means that other more nuanced definitions of place identity may be identified. "It can be found by looking at a range of places, from the historic downtowns of our cities to the everyday landscapes of suburbia, using a variety of methods, including physical form analysis, observations, interviews and other sociological methods. This new definition should consider the need for memorable and imageable environments, expressions of shared social values, new forms of nonplace communities, and the multiple mechanisms by which meanings are embedded and communicated in the landscape" Southworth and Ruggeri $(2010,510)$.

\section{THE CREATIVE URBAN TRANSFORMATION}

\section{Main Factors In Creative Regeneration}

The first two elements, which are fundamental in creative urban transformation, are place identity and innovation. Based on the aforementioned interpretations, the role of identity should be understood within the project of transforming the city in a creative manner (Landry, 2006, 2008; Scott, 2006), assessing the potential of design and planning tools as regards urban identity, and integrating them (Neil, 2004).

Although at a first glance place identity and innovation could seem quite different, if suitably mixed they actually constitute the main factor of success. Recognising the value of place identity as a key-component in implementing urban change serves as a reference point both in terms of society's wishes and in safeguarding and constructing the sustainable urban image (Carter et al., 1993; Castells, 1997).

The creative city is a city, which is able to generate economies of innovation, cultures, research and artistic production, strengthening its own identity capital. It is a question not only of boosting the economies of culture but also producing new economies, starting from cultural capital, which is seen as an element of the maximum expression of place identity - both tangible and intangible - and forming a system together with other urban capital (Carta, 2007; Hague and Jenkins, 2005). 
Culture is a resource that occupies a pivotal role in socio-economic development. Indeed, the industry of culture covers a set of activities, such as cultural heritage services, fundamental to launch a country's economy. Florida (2002) has observed the relationship which exists between changes in the capitalist mode of production - in particular those occurring at the urban scale including clusters of high-tech firms, the dissemination of leisure activities and urban economic networks - and changes in terms of identities of the actors involved. He argues that the more cities are able to seem attractive to the creative class of workers and managers in the various sectors of economy such as art, design, fashion and advanced technologies services, the greater are the chances that those cities can successfully face the challenges of competition among cities imposed by globalization (Keivani, Mattingly, 2007). Indeed, creativity is found not only in the typical characteristics of the entrepreneurial spirit but also in forms such as the spread of behaviour that is favourable to cultural exchange as well as the enhancement of lifestyle diversity.

One must also consider who are the promoters and beneficiaries of the creative city to prevent disadvantaged players being considered less influential in urban regeneration and, in general, in the success of the desired transformation. The most successful urban regeneration projects are those where there is a strong involvement of local pre-existing identity and where recovery of the sense of place, history and belonging to the local community is expected (Comunian and Sacco, 2006; Sepe, 2006). In this way, the creative city recognises complexity and addresses the spatial, physical and land use conditions, which help people to think and act with their imagination, and live the city as a satisfying experience.

Attraction and sustainability are the second pair of factors for which, although in apparent contrast, a proper balance assures the success of the creative process and results on the territory. In both of the case studies which will be presented, the respect of the environment was interpreted as an occasion of development and improvement of liveability of the places, such as the creation of specific public spaces, the particular way of shaping the vegetation, and so on. As the literature shows us, the experiences of creative cities can lead to promotion of areas of cities which base their competitiveness on local peculiarities related to the value of the "city brand" and also highlight the possibility of guiding evolution of urban systems in the city (Anholt, 2007a; 2007b). Such city areas become true creative clusters as a result of innovative economic and structural initiatives, implemented within appropriate local development strategies based on territorial quality and excellence (Carta, 2007). In this way, new urban landscapes are created according with the new brand.

The formation of creative clusters must be accompanied by the construction of lines of action to make the factors of development, enabled by the cluster, consistent with the identity and sustainable growth of the city (Nijkamp and Perrels, 1994; Richards, 2006; Sacco and Tavano Blessi, 2005). Creative resources are usually more sustainable than physical ones: monuments and museums are inevitably subject to degradation, while creative resources are constantly renewable.

In particular, the use of heritage buildings and post-industrial districts and buildings in economic and cultural regeneration is now a staple of western and possibly even global planning (Erdoğanaras and Erol, 2013; Mommaas, 2004). One element of this regeneration has been the use of creative and artistic industries in the conservation and regeneration of urban space(s). 
Post-industrial areas have seen the birth of services as museums, art centres, stores, beside the production of goods belonging to the typical cultural heritage of the areas.

These services have influence on the local cultural habits and on the tourism and new forms of creative economy. Industrial creative districts do not possess characteristics of homogeneity; in practice, they can have different peculiarities, both for dimension and importance: from a little context of handicraft laboratories to the movie studios of Cinecittà in Rome, or Art zones such as 798 in Beijing and M50 in Shanghai.

These type of districts possess a high capability to produce culture thanks to the strong presence of artists and spaces for creation and presentation of artworks, like a sort of City of Culture, but they do not possess a rich historic-artistic patrimony (monuments, public squares, etc.) like the classic typology of City of Art.

As Crang $(1998,128)$ pointed out, "although enclosed environments have multiplied, there has also been a renaissance of the city in all parts of the city itself as an arena of consumption". One of the reasons is a process of urban creative regeneration (Florida, 2005) which is transforming deindustrialized areas into new spaces of consumption. Different kinds of places have emerged such as Hafencity in Hamburg, the Albert Dock in Liverpool Arabianranta in Helsinki, Abondaibarra in Bilbao, to cite some examples in European cities (Sepe, 2009; Porfyriou and Sepe, 2017). In these cases the transformation was the start up point in order to revitalize in a creative perspective not only the image of the area in question but the whole city. In other cases transformation was more focused on the regeneration area: "What were once landscapes of labour become landscapes of leisure; former docks and factory sites become arts centres, are renovated for accommodation or form the sites for new festivals" (...) In Manhattan, Zukin (1982) identified this with the return to the city by "professionals", often in creative or media industries, taking up living in the lofts of SoHo. Conflicts can emerge over the different meanings groups ascribe to urban areas - over both residential and commercial development. Thus London's Spitafields market redevelopment produced diverging views on whether the market should be kept as a local facility, an updated national market or as a tourist attraction" (Shirley, Neill, 2015, 18). The concept of industrial creative district, which has been introduced above, has further been elaborated with reference to Chinese cities (Yu, 2014).

As Shin-lian (2014) has pointed out, two categories can be identified. The first concerns the districts created by renovation of old buildings and factories which are frequently found in major cities such as Beijing and Shanghai. These factories, and streets and houses in the surrounding area, were in many cases transformed into art or cultural districts including facilities for tourists and visitors. The 798 Art Zone in Beijing's Dashanzi Art District and M50 in Shanghai are included in this category and support the mobilization and engagement of the government with the recovering warehouses and old factories.

The second category is focused on entertainment areas connected to cultural activities as well, which include theme parks and performing arts areas. These districts, such as the area of Xintiandi in Shanghai, receive government support at different stages. In the last years, Chinese Government has invested many financial resources in order to support and incentivise these kinds of districts, even though the operations have not 
been successful in all cases (Fulong et al. 2007; Shi-lian, 2014). With respect, artists, as explained below, play an important role.

\section{The Role of Artists}

The role of artists in urban regeneration is important even though it has different meanings. Artists prefer marginal urban spaces because these represent non-globalized spaces to express their artistic identity. As Zhong (2015) observes, consumption preference by artists for urban amenities such as coffee shops, museums and exotic restaurants constitutes a strong appeal for middle class, nowadays who are in search for edgy lifestyles. The result in many cases is a transformation of artists' neighbourhood with a consequent displacement of the previous inhabitants in other places. The new inhabitants are often more rich in financial terms than in cultural ones. As noted by Lloyd (2006) the attraction of artists is given by the romanticism related to their profession, which because associated with a creative freedom, takes distance from economic or political interests. The choice of poverty and then of living in marginal spaces create around the artists a sort of social niche which make these spaces, as before mentioned, attractive for people and, consequently, for operation of marketing-oriented territorial transformation.

In China, as will be illustrated in the case study section, the artist's identity is different. In Maoist period the role of artist and his art was related to the political propaganda. Although the art world is nowadays changing, the romanticism related to social responsibility still influences the public perception (Wu, 1999). Only in few cases such as the cases of 798 in Beijing and M50 in Shanghai artists have sought to take distance from state control of cultural production (Zhong, 2011). However, the glamor around these places started to disappear after the use of capital to change urban spaces and generic commercial practice begins to eliminate the artistic originality (Currier, 2008; 2012).

On the other hand, as Florida argues, artists can contribute to the creative urban regeneration. Indeed artists are part of the creative class and contribute to attract other creative people to the regeneration of the city. However (Zheng, 2011), in China urban contexts, these kinds of processes of transformations of places are more difficult and not always the business behaviours made by local government to attract talents has led to improve the urban competitiveness.

Furthermore, it is necessary to consider the use of terminology related to both cultural and creative industries, which is changed over the years according with different geographical contexts. As explained by McCarthy and Wang (2016) the term cultural was mainly used until the mid-1990s and then substituted by the term creative industries. The use also depend on the geographical area: while the term cultural industries in still referred to Japanese and Korean areas, the term creative industries are more often referred to Chinese areas.

As regards cultural industries, Evans (2009) asserts that they both generate creative content and a sort of mix between cultural industries and tourism. The creative industries, as Caves (2000) defines, are supplying goods and services which can be associated with cultural, artistic or entertainment value and include visual arts, performing arts, fashion, cinema and sound records. 
The City Government of Beijing, in the framework of the 2005 9th Party Committee of Beijing adopted the term cultural and creative industries'(Hui 2006) to promote these industries as capable to involve cultural content and creative outputs. As regards, in Beijing the creative industries comprise 9 sectors including culture and art; advertising and exhibition; crafts and antiques; design services; tourism and leisure entertainment.

Another relevant difference with respect to the both cultural and creative cluster is the use of areas or quarters in relation to urban regeneration processes. Propris and Hypponen (2008) assert that a creative quarter involves a creative community and a space, where people and ideas can interact. As regards the terms "cluster", "quarter" and "district" Cinti (2008), as mentioned by McCarthy and Wang (2016) these terms describe an area with a concentration of cultural uses which create a needs of further services and activities aimed at achieve a "creative milieu". In China, particularly in Shanghai, Zheng (2011) refers to the term "creative industry clusters", as clusters of main production of activities in the cultural sphere.

\section{METHODOLOGY}

Research into the best practices of urban regeneration in Europe and China involved reading the specialised bibliography and consulting web sites featuring regeneration projects, using key words to retrieve data not available in the works consulted. It also involved carrying out onsite inspections with photographic documentation, meeting participants in the process and gathering specific materials. It was decided that the case studies should focus on cities where regeneration process has meant redefining the identity not only of that particular place but also of the city as a whole or of the surrounding areas. The first cases are the examples of the Abandoibarra district in Bilbao (Sepe, 2009), the area between the old El Portillo station and the new Delicias station in Zaragoza, HafenCity in Hamburg, the old port in Genoa, Marseille Euromediterranée in Marseille, Lyon Confluence in Lyon, Bordeaux Les deux Rives in Bordeaux. The second cases include the new Liverpool waterfront, Arabianranta area in Helsinki, the new waterfront of Barcelona, M50 Art District in Shanghai, Hankou waterfront in Wuhan and 798 Creative district in Beijing. As a first step, the cases have been divided up according to the projects' underlying motivation: great cultural poles, major events and environmental policies.

The cultural poles comprise buildings and areas with a cultural use - museums, art galleries, concert halls, aquariums, etc. - that become landmarks for the territory - such as M50 Art District in Shanghai and 798 Creative district in Beijing - and are in general designed or recovered by internationally renowned architects. Such projects ensure that the part of the city undergoing regeneration gains in appeal and contribute to increasing the area's economic value.

Major events constitute another important factor in starting up a regeneration process, both for the financing they generate and for the international fame associated with the event. Many regeneration projects have begun from an international event such as the Venice Biennials, the European Capital of cultures, the international exhibitions. In many cases, the success of the event gives credibility to the local authorities and ensures subsequent funding. 
Environmental policies characterise many of the current regeneration projects in Europe and China are practically a trait d'union. In some cases, however, attention to the environment and landscape becomes the prime feature, where policies have long focused on the landscape also in social and economic terms. In this perspective, the cases of Bordeaux, Lyon in Europe and of Wuhan in China are emblematic for their combination of urban and landscape projects to ensure a greater sustainability for the area in question and the city.

The investigation also seeks to identify the issues encountered and the state of advancement. Furthermore, the information on urban projects has been extended by analysing three aspects of the area surrounding the city: geography; historical evolution; creative regeneration which are of particular interest for the following case studies.

\section{THE CASE STUDIES}

\section{The 798 Art Zone}

History of the place:

The 798 Art District, whose original name was "Factory 718" embodying socialist ideals, was built in the 1950s in Chaoyang District, in the outskirts of Beijing.

The whole area is about $640,000 \mathrm{~m}^{2}$, while the surface devoted to the factory, following an East German design, is about $149,800 \mathrm{~m}^{2}$ and the project cost the equivalent of about 140 million RMB. Between 1953 and 1957, 156 projects were under construction with Soviet financial support. The first idea was to build three factories in east outskirts of the city to contribute to the national security, by producing tubes, converters and components. The project, which was entrusted to the Bauhaus University Weimar, presents that typical architectonic style with no decorations and form which follows function. Furthermore, because of the history of high-magnitude earthquakes, the factory was built using highly resistant materials capable of withstanding situations of environmental risks.

The factory was inaugurated in late 1957 both by leaders of the German Democratic Republic and Beijing and was immediately defined as the model socialist factory. In that complex, many amenities were present including sports facilities, classrooms for evening courses, dance halls and hospitals. Furthermore, it was conceived as an industrial ecosystem capable of recycling products from the manufacturing process.

The products, which were built by the factory workers, were used in many important squares and streets of Beijing and for components of the first Chinese guided missiles. The factory had a great reputation worldwide, employing approximately 10,000 workers.

Place identity and creative transformation:

In the 1990's a period of crisis started. The government decided to support the state-owned abandoned warehouses helping artists to establish their activities in the wide space of the factory. About $120000 \mathrm{~m}^{2}$ are rented to artists, shop owners, art foundations, restaurants etc. Nowadays the general atmosphere of this area is both urban and international due to the proximity to Beijing Capital Airport and the Airport Expressway. The success of the regeneration of the 798 Art Zone is evidenced by the fact that it has become an attractive place both for Chinese and foreign tourists - 

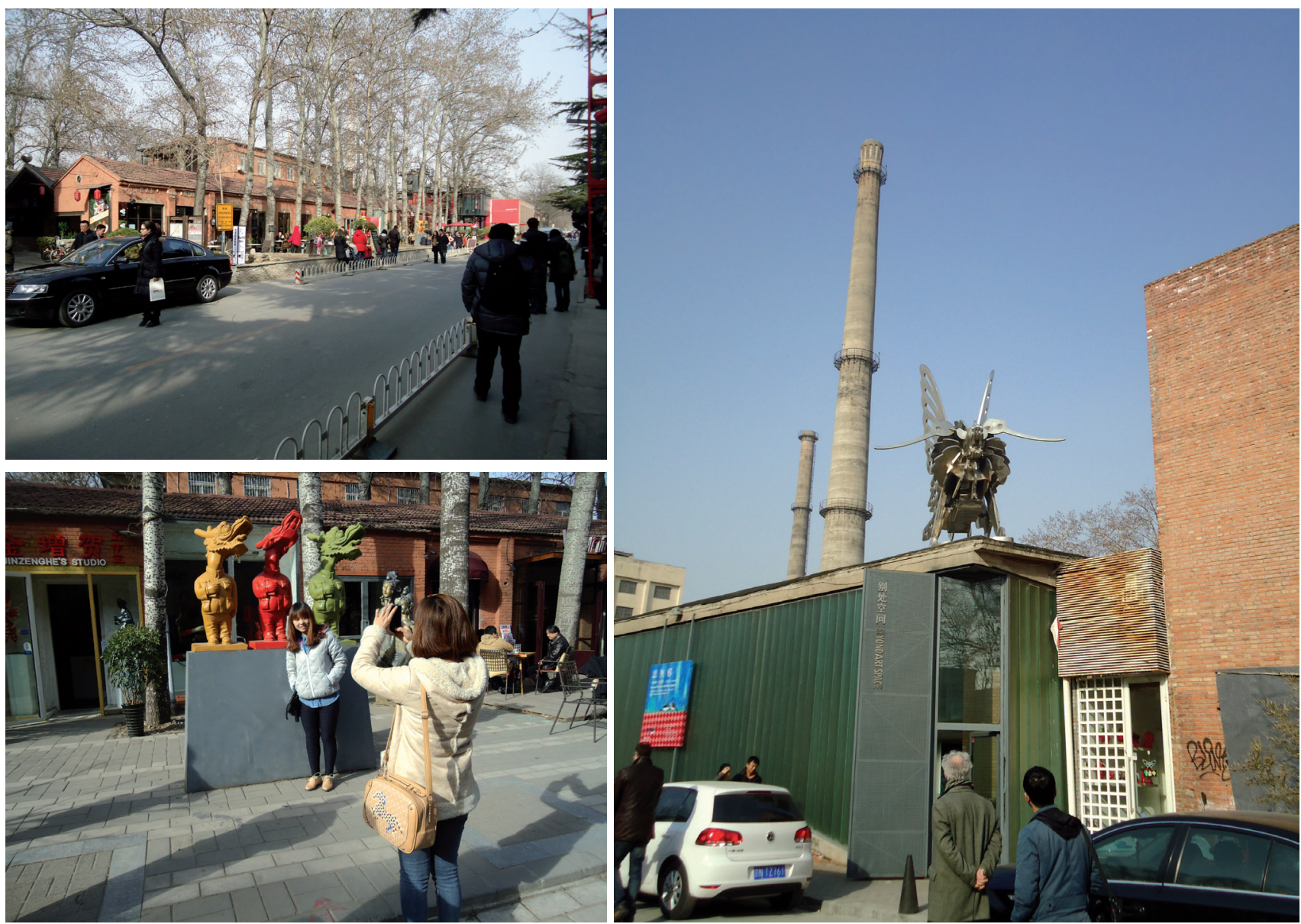

Figures 1-3. Beijing 798 Art District. Source: Author's Archive with a large number of visitors in particular during the weekend - and the value of the land for this reason is increasing rapidly.

The reputation of this place has improved since 2003, when local artists and art houses interested in increasing the awareness of the brand of this area organized many exhibitions and festivals. These were held in order to contrast with the proposed demolition of the 798 by the Seven Stars Group. The large numbers of tourists attracted by the events of 2003 demonstrated the economic importance of that place, which if demolished would be lost.

For this reason, the national and municipal governments have started to support the 798 Factory and declared it as a "Creative Culture Enterprise". From that moment, the factory has played an important role in the city marketing of Beijing, contributing to the improvement of the image of the city and making it increasingly competitive both domestically and internationally.

There are probably two reasons for promotion of the 798 Factory by Chinese Government. Firstly, the previous model factory represents a memory of a quite positive story about a period in China's history. Secondly, some professors of the Academy of Arts and Design at Qinghua University have affirmed that the 798 Factory has a strong international potential. In this way the development and support of the 798 Art Zone has the double effect of both representing China's socialist legacy and the international artists avant-garde. The appeal of the 798 Factory is increasing, becoming the backdrop for commercial or wedding photos. 
Some of these photos are collected and displayed on a wall of the factory, testifying the trendy image of the area. (Dekker, 2011).

The contemporary art scene arose after the death of Mao Zedong. In Maoist period, art was only conceived as a political message of the regime. The only form of art that was allowed was the propagandist posters, which were a mix between Chinese folk culture and socialist realism. With the rise of more moderate politicians and the abolishment of the personality cult for the Chinese leaders along with their related propaganda posters, a more artistic freedom started. The first art movements, which began in this period, include the Stars Group, which ended after the Tiananmen Square incident. In this occasion, many artists, in order to escape government monitoring, decided to move to artist villages situated in the outskirts of Beijing. These villages can be considered the precursors of the 798 Art district.

Indeed, many Chinese have difficulty in identifying themselves with contemporary Chinese art because since 1976 the connection between folk art and contemporary art has become increasingly weaker. Since that period, many artists have worked underground and even now, that scene continues to attract contemporary artists as well.

The Art District became famous after the 2003 Art Exhibition, and later - as aforementioned -, the government decided to promote and support it. After this, its popularity increased and the underground image of 798 became a brand.

Due to this new brand and popularity, 798 Factories strongly influences the art district: many shops, bar and restaurants have established there and the number is still increasing. As a result, house rent per square metre has risen sevenfold in 15 years. The high prices make it more economically attractive to rent a gallery in the 798 rather than a workspace there (Harvey, 2006). As McCarthy and Wang (2016) observed, "the changing cultural activities and components in the Zone from 2003 to 2009 can be seen with increasing galleries and decreasing artists' studies for instance, as well as increasing cafes and restaurants, illustrating a broad shift from production- to consumption-based uses. Specifically, while artists' studios dominated the use mix in 2003, the trend since then has been for an increasing proportion of galleries, as well as boutiques and cafes and restaurants". With respect, average rents increased from $20 \mathrm{RMB} / \mathrm{m}^{2} /$ month in 2003 to $150 \mathrm{RMB} / \mathrm{m}^{2} /$ month in 2013. (Sun, 2012; McCarthy Wang, 2016).

In this way, young artists - above all local - have problems affording a space to exhibit their works, allowing large overseas companies to rent a gallery there. In addition, artists who still work in the 798 have decided to leave the area due to the unfavourable working environment.

Furthermore, the popularity has also had other kinds of effects including changes in the artworks. Because of the high rent, artists have had to earn significant profits in order to afford the workspace in the factory. This has caused artists to start to produce artworks aimed at more easily meeting the tastes of potential buyers.

In that way, 798 Factories is changing its original identity from a place where edgy art was produced to one where more conforming and globalized art is realized. This represents both a danger as such a globalized place could lose its appeal in the future, and simultaneously a district which could better recreate the lost bond between folk and 
Figures 4-5. Shanghai M50 Art District. Source: Author's Archive contemporary art and make Chinese people identify with that art (Dekker, 2011).

\section{The M50 Art District}

History of the place:

In Shanghai, during the mid-1990s, many warehouses were recovered. Teng Kun-Yen, a Taiwanese architect, who rented a warehouse in Suzhou Creek and decided to move there with his studio, recovered one of the first warehouses. Many others have followed Teng's case, such as M50.

The popularity of these spaces grew and in that period new legislation on conservation was introduced $(\mathrm{Gu}, 2012)$. As a result, conservationists started to admire artists' works and their influence. The municipal government recognized the economic potential of the increasingly prevalent cultural rehabilitation of industrial buildings.

The recovering of the abandoned warehouses covered many possibilities which government considered for generation of new employment and higher gross domestic product $(\mathrm{Gu}, 2012)$ The Shanghai Municipal Economic and Information Technology Committee (SHEITC) decided to propose the creation of the Creative Industrial Agglomeration Area to reuse industrial heritage for creative firms. In 2004, in order to achieve this, the semi-governmental organization Shanghai Creative Industry Center was created. The term industrial heritage was rapidly spread in politics and the media. In few years, in connection with the 2010 Expo, the Master Plan for Urban Sculpture was approved. Through the idea of building a Shanghai Sculpture Space by renovating abandoned warehouses, the government aimed to transform industrial structures and their surroundings in public art centres.

Place identity and creative transformation:

One of the most popular art centres in the Suzhou Creek cultural zone in Shanghai is M50, which, with more than 50 buildings, occupies an area of $24,000 \mathrm{~m}^{2}$. The original function of the place was a textile factory built before 1949 by Chinese entrepreneurs and international capitalists. The buildings were made of brick and wood with large industrial windows, which provide the light for the workspaces $(\mathrm{Gu}, 2014$; O'Connor and $\mathrm{Gu}$, 2014).
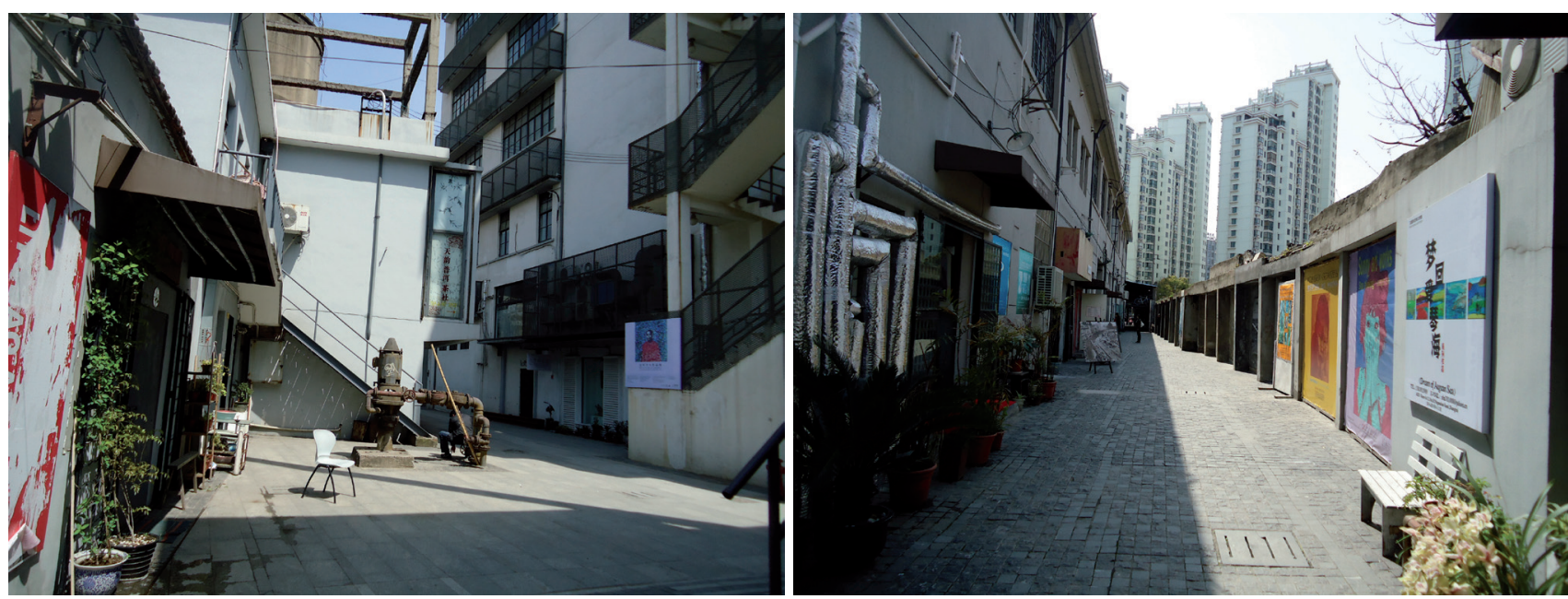
This kind of architecture was suitable to local artists, who started to rent their workspaces in the 1980s, when the factory ceased production and was abandoned. About 150 artists from China and abroad and some architect and design firms have chosen to base themselves there. The main art galleries, which were established there, including ShanghArt (Swiss) and BizArt (British), have an interest in promoting Chinese contemporary art. These galleries have the important role of intermediary between Chinese contemporary artists and the international art market.

As $\mathrm{Gu}(2014)$ stated, an elective affinity existed between warehouses and artists' identity, which have a profound root. Indeed, few artists have chosen to use the past industrial urban landscape of Shanghai as the backdrop to their art productions. Artists decide to move to M50 because of the existence of both an art community and a network, which could increase the likelihood of meeting collectors.

The appearance of warehouses seems today resemble an international artists cluster, although indeed a link between the artists' identity and the meaning of the place does not always exist. As previously mentioned, artists decide to move there to find easier access to the Chinese contemporary art market. In the M50 there are many art productions, which decorate public spaces, but the sense of a communal space does not emerge. Artists socialize elsewhere - such as in their studios - and for this reason the cultural identity is quite superficial because there is no interaction between artists. In this way, the M50 could change into an art market space in the future where management companies could impose their market rules. Indeed, this place has attracted many people who are interested in Chinese contemporary art and galleries, which are involved in purchasing Chinese artistic productions. Furthermore, people who visit that space are interested in a better understanding of the artist's life and work here.

As Zielke and Waibel (2014) declares, as the Beijing 798 two phases can be observed:

"During the first phase of bottom-up development, M50 was continuously threatened by the real estate ambitions of Shangtex and the local state, prompting artists to organize into groups to fight against demolition. (...) After protection was ensured in 2004, a "phase of consolidation" began. Shangtex became the investor and instituted a public-private management organization to oversee the area. This institutional innovation allowed the local state and operator to regain control, and their powerful economic and image-making objectives were consequently balanced".

Indeed, in 2000, the M50 became an official creative cluster managed by the public venture company Shanghaitex group. This has resulted in an increase in rent, which has caused, as in the 798 case, artists difficulty in retaining their spaces. Simultaneously, as an industrial heritage site, M50 is not an ideal place for commercial developers and regeneration plans, maintaining the possibility for artists to retain their spaces, representing a potential for the conservation of such sites. Indeed, there are many reasons, which discourage the regeneration plans making them not profitable for developers. Firstly, in accordance with Chinese policy, it is difficult to change the original purpose of a plot of land, making it quite hard to convert warehouses into residences. Secondly, it is costly for developers to maintain the character of buildings. Thirdly, it is not possible to change the ownership of a heritage site. Finally, developers have to provide employment for the former workers of the closed factories in the 
new regeneration area, which represents a problem because often they subcontract these jobs to other companies $(\mathrm{Gu}, 2014)$.

However, in the next years, M50 could risk losing its reputation as a centre of Chinese contemporary art because artists are more and more marginalized. The market forces, which for their economic interests contribute to the increasing rent of workspaces and the separation of the Art District from the bordering area, are resulting in the creation of an art (Wang, Lau, 2009) space. However, artists and creative people could improve the image of the place, making it more attractive from an aesthetic point of view, which would maintain government enthusiasm for preserving heritage buildings.

\section{DISCUSSION AND CONCLUSION}

The paper started with a critique of globalisation and the loss of place identity in contemporary city. A reconfigured phenomenology is meant as critical to rescue more and more urban spaces from a continuing global process of branding.

To explore these issues in detail both the rise of the creative transformation phenomenon and the role of artists - with particular attention to the Chinese contexts - are illustrated and the urban development through historical districts and heritage sites is explored: more specifically industrial heritage sites that are now in disuse.

As it has been explained in the paper, in contemporary China the artist is a very controversial figure. In Maoist period the role of artist and his art was related to political propaganda. Even though the art worlds are nowadays changing, the romanticism related to the social responsibility still influences the public perception. Only in few cases, such as 798 in Beijing and M50 in Shanghai, artists have sought to take distance from the state control of cultural production. However, the glamor around these places started to disappear after the use of capital to change the urban spaces and generic commercial practice begins to eliminate the artistic originality.

These factors constitute the background for illustration of two creative regeneration case studies in the two before mentioned famous art zones in Beijing and Shanghai, namely 798 and M50 respectively, which have many elements in common including two phases of development: one bottom-up and one top-down.

The popularity of 798 Art Zone has different effects. Because of the increasing rent, artists have had to earn significant profits in order to afford workspaces in the factory. This has caused artists to start to produce artworks aimed at more easily meeting the tastes of potential buyers. Consequently, 798 is changing its original identity from a place where edgy art was produced to one where more conforming and globalized art is the main output. This represents both a danger as such a globalized place could lose its appeal in the future, and simultaneously an opportunity to better recreate the lost bond between folk and contemporary art and make Chinese people identify with that art.

"The reputation and popularity of the Zone has clearly been a significant factor contributing to its commercial success as a centre of consumption. In a 2009 survey of 21 creative areas in Beijing, the Zone was second in terms of popularity, fourth in terms of favourability, fourth in terms of development potential and sixth in terms of influence" (Zeng, Wang 2009). 
As regards the other case study, in the next years, M50 Art District could have the similar danger of losing its originality as a centre of Chinese contemporary art because artists are more and more marginalized. The market forces, which due to their economic interests contribute to the increasing rent of workspaces and the separation of the Art District from the bordering area, are resulting in the creation of an art space (Ley, 2003; Viejo-Rose, 2011). As affirmed by Wang (2009),

"The transformation of a place may generate economic returns, but in the process it results in gentrification and social exclusion. (...) The irony is that while the project was initially based on artists' space consumption, these artists themselves - particularly the struggling ones - were not truly welcome in the new creative community".

Simultaneously, as an industrial heritage site, M50 is not an ideal place for commercial developers and regeneration plans, maintaining the possibility for artists to retain their spaces, representing a potential for the conservation of such sites. Furthermore, artists and creative people could improve the image of the place, making it more attractive from an aesthetic point of view, maintaining government enthusiasm for preserving heritage buildings.

In the two cases, it is important not to place too much stress on tourist development where the term "cultural" is an instrument rather than a quality: for sustainable development, a real engine of change, the "cultural" element must offer quality to tourism not vice versa. The more value is given to the local cultural peculiarities - such as cultural heritage and place identity - the more the operation of urban regeneration may be embedded within the local fabric and be attractive for residents and visitors.

As many European cases demonstrate, including Bilbao, Bordeaux, Helsinki (Sepe, 2009), important contributing factors to the success of operations of these kinds are provided by creating the identity of the neighbourhood starting from the place and its history, constructing the most suitable urban policies and strategies, and involving residents, artists and visitors in many ways and situations. Furthermore, another important element is creating a mixed-use place, not only related to art, but also including residences, public spaces and amenities.

Furthermore, the Chinese cases, as stated by Kunzmann and Yan (2013), suggest "the need for creative clusters to more sensitively balance uses and activities so as to maintain a degree of their original core artistic orientation and content, to ensure that benefits are sustainable. This implies the desirability in such cases of a change in orientation away from consumption-related aims linked for instance to tourism and real estate priorities, which in sum perhaps represent a short-term focus, towards broader strategic priorities for entrepreneurial growth and sustainable economic development, linked to core artistic capital and maximization of agglomeration benefits and linkages".

This suggest lighter interventions through place-making activities and key infrastructure development rather than strong top-down operations aimed at rapid transformation and consume of culture. Finally, a more evident participation of both inhabitants and local artists in the creative transformation could provide a more profound connection between locals and the place. 


\section{ACKNOWLEDGEMENT}

This paper was written in the framework of the EU - FP7-PEOPLE-2011-IRSES Planning,

Urban Management and Heritage (PUMAH).

\section{REFERENCES}

AAVV Best of Beijing: 798 Guide 2012-2013, Beijing

ANHOLT, S. (2007a), Competitive Identity: The New Brand Management for Nations, Cities and Regions, Palgrave MacMillan, Houndmills and New York

ANHOLT, S. (2007b), The Anholt City Brands Index 2007 general report, www. business.nsw.gov.au, access July 15 ${ }^{\text {th }}, 2017$

BAGWELL, S. (2008) 'Creative Clusters and City Growth', Creative Industries Journal 31(1) 31-46.

BAUMAN, Z. (2004) Identity: Conversations with Benedetto Vecchi, Polity Press, Cambridge

BANERJEE, T., SOUTHWORTH M. Eds (1990), City sense and city design, MIT Press, Cambridge (Mass)

BENTLEY, I. (1999), Urban Transformations: Power, people and urban design, Routledge, London

CARTA, M. (2007) Creative city, LISt, Barcelona

CARMONA, M., HEATH, T., OC, T., TIESDELL, S. (2010) Public placesUrban spaces, Oxford: Architectural Press.

CASTELLS, M. (1997) The power of Identity, Blackwell, Malden.

CHEN, F., THWAITES, K. (2013) Chinese Urban Design The Typomorphological Approach, Ashgate, Surrey

CINTI, T. (2008) "Cultural Clusters and Districts: The State of the Art" in Creative Cities, Cultural Clusters and Local Economic Development, P. Cooke, L. Lazzeretti (eds), Cheltenham, Edward Elgar, 70-92

COMUNIAN, R. AND SACCO, P.L. (2006) NewcastleGateshead: Riqualificazione Urbana e Limiti della Città Creativa, Working paper, Venezia: Università Iuav di Venezia.

CRANG, M. (1998) Cultural Geography, Routledge, London

DEKKER R. (2011) 798 Art Zone Beijing, Site of 'Cultural Revolution' or Showpiece of City Marketing?, Master thesis of Science in Conflict and Development in University of Ghent, Faculteit Politieke en Sociale Wetenschappen

ERDOĞANARAS, F., EROL, D. (2013) The Impact Of Manufacturing Industry Decentralization On Jobs-Housing Relationship And Commuting Behavior: The Case For The Sincan And Ostim Organized Industrial Districts, METU Journal of the Faculty of Architecture 30(1) 139-63

FERILLI, G., PEDRINI, S., (2007) Il Distretto Culturale Evoluto alla Base dello Sviluppo Sostenibile del territorio, in Pre-Proceeding IPSAPA 2007, Cividale del Friuli - UD, 25-26 October 2007.

FLORIDA, R. (2002) The Rise of the Creative Class and How It's Transforming Work, Leisure, Community and Everyday Life, Basic Books, New York 
FLORIDA, R. (2005) Cities and the Creative Class, London, Routledge, New York.

FULONG, W., XU, J., YEH, A: (2007) Urban Development in Post-reform China. State, Market, and Space, Routledge, London.

GOSPODINI, A. (2004) 'Urban Space Morphology and Place-identity in European Cities; Built Heritage and Innovative Design', Journal of Urban Design 9(2) 225-48.

GRAHAM, B., Ed. (1998) Modern Europe - Place, Culture, Identity, Arnold, London

GRAHAM, B., HOWARD, P. (2008) Introduction: Heritage and Identity, The Ashgate Research Companion to Heritage and Identity, (eds.) in Graham, B., and Howard, P, Aldershot, UK: Ashgate. 1-18.

GU, X. (2012) The Art of Re-Industrialisation in Shanghai, Culture Unbound, $4,193-211$

GU, X. (2014) Cultural Industries and Creative Clusters in Shanghai, City, Culture and Society 5, 123-30.

HAGUE, C., JENKINS P. Eds. (2005), Place Identity, Participation and Planning, Routledge, Abingdon.

HARVEY, D. (2006) Spaces of Global Capitalism: Towards a Theory of Uneven Geographical Development, Verso, and London.

HUI, D. (2006) From Cultural to Creative Industries: Strategies for Chaoyang District, Beijing, International Journal of Cultural Studies 9(3) 317-31.

JIAMING, S., SCOTT L. (2013) Chinese Globalization, A Profile of People-Based Global Connections in China, Routledge, London

KEIVANI, R., MATTINGLY, M. (2007) The Interface of Globalisation and Peripheral Land in Developing Countries: Implications for Local Economic Development and Urban Governance, International journal of urban and regional research 31(2) 459-74.

KONG, L. (2007) Cultural Icons and Urban Development in Asia: Economic Imperative, National Identity, and Global City Status, Political Geography 26 383-404

KUNZMANN, K., YAN T. (2013) Creative Cities in Practice: European and Asian Perspectives, Beijing, Tsinghua University Press.

LANDRY, C. (2006) The Art of City Making, Earthscan, London.

LANDRY, C. (2008) The Creative City: Its Origins and Futures, Urban Design Journal, 106.

LAWLER, S. (2013) Identity: Sociological Perspectives, Wiley, UK.

LEY, D. (2003) Artists, Aestheticisation and the Field of Gentrification, Urban Studies, 40(12) 102-107.

LYNCH, K. (1960) The Image of the City, MIT Press, Cambridge, Mass.

MASSEY, D., JESS, P. eds. (1995) A Place in the World? Place, Cultures and Globalization Oxford: Open University/Oxford University Press. 
MCCARTHY, J., WANG, Y. (2016) Culture, Creativity and Commerce: Trajectories and Tensions in the Case of Beijing's 798 Art Zone, International Planning Studies 21(1) 1-15.

MCCARTHY, J., (2006) Regeneration of Cultural Quarters: Public Arts for Place Image or Place Identity?, Journal of Urban Design 11(2) 243-62.

MCDOWELL, S. (2008) "Heritage, Memory and Identity" in Graham, B., and Howard, P. (Eds), Introduction: Heritage and Identity, In the Ashgate Research Companion to Heritage and Identity, 37-53, Aldershot, UK: Ashgate.

MOMMAAS, H. (2004) Cultural Clusters and the Post-Industrial City: Towards the Remapping of Urban Cultural Policy, Urban Studies 4(3) 507-32.

NEIL, W.J.V. (2004) Urban Planning and Cultural Identity, Routledge, New York.

NIJKAMP P., PERRELS A.H. (1994) Sustainable Cities in Europe, Earthscan, London.

O'CONNOR, J., GU, X., (2010) Developing a Creative Cluster in a Postindustrial City, The Information Society 26(2) 124-36.

O'CONNOR, J., GU, X., (2014) Creative Industry Clusters in Shanghai: a Success Story? International Journal of Cultural Policy 20(1) 1-20.

PENDLEBURY, J, ERTEN E, LARKHAM P, Eds. (2014) Alternative Visions of Post-War Reconstruction: Creating the Modern Townscape. London: Routledge.

PENDLEBURY, J. (2013) Conservation Values, the Authorised Heritage Discourse and the Conservation-Planning Assemblage, International Journal of Heritage Studies 19(7) 709-727.

POZO, P.D., GONZALES, P.A. (2012) Industrial Heritage and Place Identity in Spain: from Monuments to Landscape, Geographical Review 102 446-64.

PORFYRIOU, H., SEPE, M. (2017) Waterfront Revisited, Routledge, LondonNew York

PROPRIS, L. D., HYPPONEN, L. (2008) “Creative Clusters and Governance: The Dominance of the Hollywood Film Cluster", Creative Cities, Cultural Clusters and Local Economic Development, (Eds.) P. Cooke, L. Lazzeretti, Cheltenham, Edward Elgar 258-259

RELPH, E., (1976) Place and Placelessness, London, Pion.

RICHARDS, G., WILSON J. (2006) ‘Developing creativity in tourist experiences: A solution to the serial reproduction of culture?' Tourism Management 27(6).

ROSE, G. (1995), Place and Identity: a Sense of Place, A Place in the world? Place, cultures and globalization, (Eds) Massey D., Jess P. Open University/Oxford University Press, Oxford, 87-132;

ROWE, C., KOETTER, K. (1978) Collage City, MIT Press, Cambridge, Mass.

SACCO, P.L., TAVANO BLESSI, G. (2005) Distretto Culturale e Aree Urbane', Economia della Cultura, 14(2), 153-166 
SCOTT, A. J. (2006) Creative Cities: Conceptual Issues and Policy Questions, Journal of Urban Affairs, 28(1), 1-17

SECCHI, B. (2000) Prima Lezione di Urbanistica, Editori Laterza, Roma-Bari.

SEPE, M. (2009) Creative Urban Regeneration between Innovation, Identity and Sustainability, International Journal of Sustainable Development, 12(2) 3-4.

SEPE M. (2010a) Urban policies, Place Identity and Creative Regeneration: the Arabianranta case study, Proc. of 2010 14th International Planning History Society Conference, Istanbul.

SEPE, M. (2010b) Sustainable Urban Transformations in the Contemporary City: a Case of Creative Regeneration, Inhabiting the Future, Clean, Naples.

SEPE, M. (2013) Planning and Place in the City. Mapping Place Identity, Routledge, London-New York.

SHI-LIAN, S. (2014) Chinese Cultural Policy and the Cultural Industries, City, Culture and Society 5(3) 115-21.

SHIRLEY, I., NEILL, C. (2015) Asian and Pacific Cities Development Patterns, Routledge, London

SMITH, M. (Ed.) (2007) Tourism, Culture and Regeneration, Cambridge (MA), Cabi.

VIEJO-ROSE, D. (2011) Destruction and Reconstruction of Heritage: Impacts on Memory and Identity, (eds.) H.Anheier, H., Isar, Y.R., Heritage, Memory and Identity, Thousand Oaks, Sage; 53-69.

WANG, J., LI, D., (2009) The Rhetoric and Reality of Culture-Led Urban Regeneration - a Comparison of Beijing and Shanghai, China, The 4th International Conference of the International Forum on Urbanism (IFoU) 2009 Amsterdam/Delft.

WANG, J., LAU, SSY (2009) Shanghai's Professional Middle Class in the Wave of Gentrification: Reflection on Cultural Consumption Thesis Cities 26(2) 57-66.

YU, L. (2014) Chinese City and Regional Planning Systems, Ashgate, Surrey.

ZHENG, J. (2010) The 'Entrepreneurial State' in 'Creative Industry Cluster' Development in Shanghai, Journal of Urban Affairs, 32(2) 143-70.

ZENG, F. W., WANG, A. L. (2009) Research on the Influence of 21 Cultural Creative Clusters in Beijing. In Research Report on Cultural Creative Industries Clusters Development in Beijing, W. L. Niu and Y. Peng, (Eds) 105-131. Beijing: People's University of China Press.

ZHONG, S., (2015) Artists and Shanghai's Culture-led Urban Regeneration, Cities 26(6) 318-30.

ZIELKE, P., WAIBEL, M. (2014), Comparative Urban Governance Of Developing Creative Spaces in China, Habitat International 41 99107.

ZUKIN, S. (1995) The Culture of Cities, Blackwell, Cambridge, MA. 
Received: 02.12.2015; Final Text: 06.03.2017

Anahtar Sözcükler: Mekânın kimliği; yaratıcı kentsel alanlar; kentsel dönüşüm; sanat mahalleleri; Çin'de kentsel yenileme.

\section{MEKÂNIN KİMLİĞİ VE YARATICI KENTSEL DÖNÜŞÜM UYGULAMASI: PEKİN 798 VE M50 ŞANGAY SANAT MAHALLESI ÖRNEKLERI}

Bir yerin tarihi -uygun politikaların geliştirilmesi ile birlikte- şehrin bu kısmının geleceğini ve yenilenmesini (canlandırılmasını) belirlemede önemli bir unsur teşkil eder. Aynı zamanda yer kimliğinin değerini, mirasın ve kentsel değişim uygulamalarının temel bir birleşeni olarak kabul etmek, hem toplumun istekleri bağlamında hem de sürdürülebilir kentsel imgenin korunması ve oluşturulmasında bir referans noktası olarak hizmet eder. Yapılı miras anlatıları, "belirli mekanları kolektif kültür bilincinin merkezleri olarak belirterek" ulusal kimliklerin olușturulmasını ve geliştirilmesini kolaylaştırır. Bu bakımdan, kentsel mekan tasarımında yenilik, mekanların kimliğini oluşturmak ve çağdaş şehirlerin kentsel formuna küreselleşmemiş bir kapsam sağlamak için bir fırsattır. Kültür endüstrisi, bir ülkenin ekonomisini tetiklemek için bir dizi faaliyeti barındırır. Bununla birlikte, en başarılı kentsel yenileme projelerinin önceden var olan yerel kimliğin etkin rol oynadığı, tarihsel mekan hissi ve yerel topluluğa aidiyet hissinin geri kazandırılmasının beklenildiği çalışmalar olduğunu dikkate almak önem taşır.

Bu bağlamdan yola çıkarak, Makalenin amacı, Çin'deki iki yaratıcı mekan olan Beijing'deki 798 semtine ve Shanghai'daki M50'ye odaklanan yenileme sürecini tanımlamaktır. Bu alanların ortak noktası, barındırdıkları eski endüstriyel alanların yaratıcı birer parka dönüştürülmesidir. Pek çok Çin kentinin ilgisini çeken artan ekonomik büyümeye bağlı olarak, yenilenme sürecindeki risk mekanın küresel kimlik kazanması ve yer kimliğinin kaybıdır. Yer kimliği kavramı, yaratıcı yenileme ve plancının rolü ile ilgili teorik çerçeve makaleyi tamamlamaktadır.

\section{PLACE IDENTITY AND CREATIVE DISTRICT REGENERATION: THE CASE OF 798 IN BEIJING AND M50 IN SHANGHAI ART ZONES}

The history of a place constitutes - together with the development of suitable policies - an important element in determining the future of that part of the city and its renewal. At the same time, recognizing the value of place identity as a fundamental component of heritage and in implementing urban change serves as a reference point both in terms of society's wishes and in safeguarding and constructing the sustainable urban image. Built heritage narratives facilitate the creation and enhancement of national identities by "denoting particular places as centers of collective cultural consciousness". In this respect, innovation in urban space design represents an opportunity to construct an identity of places and give a no globalized scope to the urban form of contemporary cities. The industry of culture covers a huge set of activities fundamental to launch a country's economy; nonetheless, it is important to consider that the most successful urban regeneration projects are those where there is a strong involvement of local pre-existing identity and where history recovery of the sense of place and belonging to the local community is expected.

Starting from these premises, the aim of the paper is to illustrate the process of regeneration, which focuses on two creative sites in China: 798 district in Beijing and M50 in Shanghai. These districts have in common the transformation of old industrial sites into a creative park. Due to the increasing economic growth, which is of interest to many Chinese cities, the 
risk is the globalization of the process of regeneration and the loss of place identity. The theoretical framework - related to the place identity concept, the creative regeneration and the role of artists - completes the paper.

MARICHELA SEPE; B.Arch., Spec. Urban Design

Received the Laurea degree in architecture and the Specialization School degree in urban design from the University of Naples in 1991 and 1996, respectively. She is a researcher at the Italian National Research Council in Naples, a Contract Professor at the Department of Architecture of the University of Naples and also currently affiliated with the IRISS- CNR. Her research interests include urban landscape analysis and planning, urban design, post-seismic reconstruction, waterfront urban regeneration. marisepe@unina.it 
